\title{
INTERNET SEBAGAI MEDIA PELAPORAN INFORMASI KEUANGAN PADA PERUSAHAAN LQ-45 di BEI
}

\author{
Sri Andriani \\ Jurusan Akuntansi Fakultas Ekonomi Universitas Islam Negeri (UIN) \\ Maulana Malik Ibrahim Malang \\ Email: andri1375@gmail.com/HP: 081333689915
}

\begin{abstract}
Internet as a medium for reporting financial information (Case Study In The LQ-45 in IDX) is the result of research that explore the internet media in the development of accounting information systems. So some of the problems that arise are: (1) Does the LQ-45 firms listed at BEI have the homepage? (2) The extent to which the LQ-45 firms listing in BEI utilizing communication technology developments, particularly the Internet for the purposes of reporting, especially financial information to meet the needs of their stakeholders? By using the framework Pirchegger \& Wagenhofer (Pirchegger \& Wagenhofer Framework) for menganilisa websites of each company, then the obtained result of 95\% LQ-45 firms have a website and a majority of LQ-45 menggunnakan duplication of information or hard copies of historical reports that changed in the form of hypertext or pdf format. $42 \%$ of company stock prices convey information, although the majority of the home page featuring press releases, $40 \%$ who perform the update of the information displayed. Use of the majority of applications using JAVA applications ( $84 \%$ ) which is supported by the use of hyperlinks and external links in the homepage. In addition, the majority view (interface) of the sample companies are structured properly
\end{abstract}

\section{Keywords: Internet, Financial Statements}

Keuntungan kompetitif jangka panjang (sustainable competitive advantage) dan mempertahankan kesuksesan usaha, perusahaan harus mampu memenuhi ekspektasi para stakeholder-nya. Salah satunya adalah kebutuhan akan informasi keuangan maupun non keuangan yang akan dapat memberikan keyakinan pada stakeholder atas daya hidup perusahaan yang bersangkutan. Pengguna (stakeholder) membutuhkan informasi sangat bermacam-macam sehingga perubahan pendekatan bisnis dengan penekanan lebih terhadap kebutuhan stakeholder sangat penting. Stakeholder membutuhkan sistem pelaporan yang fleksibel, dimana akan dapat memungkinkan mereka memperoleh informasi dengan cara yang lebih mudah. Sehingga, metode pelaporan perusahaan yang digunakan sekarang tidak mencukupi untuk mengakomodasi kebutuhan tersebut. Salah satu sarana yang akan dapat menunjang 
perusahaan untuk dapat memberikan pelaporan yang fleksibel, relevan dan tepat waktu yang spesifik untuk stakeholder adalah dengan memanfaatkan perkembangan teknologi informasi dan komunikasi.

Salah satu perkembangan terbesar teknologi informasi dan komunikasi dalam kurun waktu setengah abad ini adalah perkembangan Internet. Internet mampu menurunkan distorsi dalam saluran komunikasi dan mengurangi serta menghilangkan pertukaran antara daya jangkau (reach) dan kedalaman isi (richness) suatu informasi (Perera et.al.: 2003). Internet merupakan suatu media yang tepat untuk digunakan sebagai sarana untuk mengakomodasi perubahan yang dibutuhan dalam pelaporan perusahaan. Berdasarkan penelitian bernama Jupiter Reserch yang dipresentasikan dalam forum "Worldwide On-Line Population Forecast, 2006 to 2011", Jupiter Reserch mengatakan bahwa tingkat perkembangan internet sebesar 38\% selama tahun tersebut, yang artinya di tahun 2011, kira-kira 22\% dari penduduk bumi merupakan pengguna internet reguler Jupiter Reserch juga mengatakan bahwa populasi pengguna online akan meningkat secara bertingkat sebesar 6,6\% lebih tinggi dari peningkatan populasi penduduk yang hanya $1,1 \%$ sebagai catatan saat ini lebih dari 1,1 milyar orang sudah dapat mengakses Web. Daerah Amerika Utara tetap akan menjadi daerah yang memiliki pengguna internet paling tinggi, diperkirakan meningkat dari 70\%-76\% pada tahun 2011, Sementara itu pertumbuhan yang paling eksplosif yakni pada negara Cina dan India, diharapkan pada tahun 2011 yang akan datang akan memiliki jumlah pengguna internet terbanyak didunia, yakni kisaran $42 \%$ dari keseluruhan populasi online didunia, atau kisaran 5\% dari kondisi sekarang.

Berbagai penelitian (Lymer: 1999, Hedlin: 1999, Pirchegger \& Wagenhofer: 1999, Deller et.al.:1999, Gowthorpe \& Amat: 1999) telah dilakukan untuk meneliti sejauh mana penggunaan Internet dalam pelaporan keuangan perusahaan, khususnya penelitian tersebut dilakukan di Inggris, Swedia, Spanyol, Austria, German, Amerika Serikat, Australia. Perusahan-perusahaan di Eropa, Amerika, Australia khususnya, menggunakan World Wide Web homepage mereka sebagai plaform untuk menyajikan data keuangan mereka, khususnya laporan keuangan tahunan, press release, dan informasi lain (Lymer: 1999, Hedlin: 1999, Pirchegger \& Wagenhofer: 1999, Deller et.al.:1999, Gowthorpe \& Amat: 1999). Dibandingkan dengan laporan keuangan tradisional (tercetak), Internet menawarkan peluang yang jauh lebih banyak dalam mengkomunikasikan informasi keuangan (Pirchegger \& Wagenhofer: 1999). 
Menurut Choi et.al. (2002) dan Perera et.al. (2003), Internet merupakan salah satu penggerak dan pendorong globalisasi. Untuk mendorong cross-listing dan crossinvestment, terutama dibutuhkan ketersediaan informasi (keuangan maupun non keuangan), dan Internet merupakan sarana dan media yang paling tepat (Choi, et.al.: 2002). Indonesia sebagai salah satu negara berkembang juga tidak lepas dari fenomena tersebut, perusahaan-perusahaan di Indonesia dituntut untuk dapat meningkatkan kemampuan mengkomunikasikan informasi (keuangan dan non keuangan) yang dimiliki untuk memuaskan stakeholder, termasuk investor.

Menurut Sayogo (2005), ada 72,5\% perusahaan teraktif yang menggunakan fasilitas internet sebagi media pelaporan keuangan, sedangkan Luciana (2009), dari hasil penelitiannya sebagai besar perusahaan belum memnfaatkan internet sebagai media pelaporannya. Kemudian permasalahan yang muncul adalah: (1) Apakah perusahaan LQ-45 yang listing di BEI memiliki homepage? (2) Sejauh mana perusahaan LQ-45 yang listing di BEI memanfaatkan perkembangan teknologi komunikasi, khususnya internet untuk kepentingan pelaporan, terutama informasi keuangan untuk memenuhi kebutuhan stakeholder mereka?

\section{Peran Internet dalam Mengkomunikasikan Informasi Keuangan}

Menurut Xiao et.al.: 2002, beberapa karakteristik internet sangat relevan untuk pelaporan keuangan sebagai media komunikasi, internet mempengaruhi aspek komunikatif dari pelaporan keuangan, seperti : (1) akses dan distribusi. Kemampuan internet untuk dapat diakses dimanapun dan kapanpun membuat data akuntansi secara elektronik akan dapat diakses secara global, (2) penyajian dan presentasi. Fitur World Wide Webt seperti hypertext, hyperlinks menyediakan potensi untuk merubah cara penyajian laporan keuangan, informasi keuangan akan dapat dihubungkan langsung dengan informasi non keuangan (Xiao et.al.: 2002). Hilangnya pertukaran antara reach dan richness akan memungkinkan perusahaan untuk men-disclose disclosure tambahan untuk memuaskan stakeholder. Penggunaan XBRL (Extensive Business Reporting Language) dalam akuntansi dan pelaporan akan memungkinkan persiapan, publikasi, evaluasi dan pengambilan informasi keuangan dalam waktu yang nyata (real time) secara on-line (Rezaee et.al.: 2001), akan meningkatkan ketepatan waktu (timeliness) informasi keuangan, (3) Interaktif. Internet akan memungkinkan komunikasi dua arah. 
Komunikasi informasi keuangan kepada stakeholder dapat dilakukan secara interaktif sehingga akan memudahkan stakeholder untuk memperoleh pemahaman lebih atas performa perusahaan.

\section{Dampak Internet Terhadap Pelaporan Keuangan}

Menurut Xiao et.al. (2002), internet akan membawa perubahan besar dalam pelaporan keuangan dalam metode distribusi informasi, pendekatan untuk akses informasi, frekuensi pelaporan, bahasa yang digunakan, maupun permasalahan politis dan sosiologis. Pertama, meningkatkan penyajian informasi kualitatif dan non keuangan. Sesuai dengan penelitian Amir dan Lev (1996), dalam industri yang intensif teknologi, investor akan menilai lebih informasi non keuangan dan berusaha untuk melakukan penyesuaian kembali atas laba yang dilaporkan (Amir \& Lev: 1996). Lebih jauh lagi, menurut Xiao et.al. (2002), internet akan meningkatkan informasi non keuangan non audit, khususnya informasi lingkungan dan sosial dengan fokus yang lebih besar atas prediksi dibandingkan data historis (Xiao et.al.: 2002). Kedua, meningkatkan disclosure. Peningkatan ekspektasi pengguna informasi keuangan dan permintaan akan informasi spesifik individual akan mendorong perusahaan untuk meningkatkan informasi yang disediakan. Menurut Craven \& Marston (1999), akhir-akhir ini perusahaan mempunyai kecenderungan untuk meningkatkan disclosure dan menyediakan disclosure sukarela di internet. Disclosure sukarela ini, seperti grafik dan foto, memberikan kepada berbagai pengguna informasi lebih sesuai dengan tujuan pengguna masing-masing (Craven \& Marston: 1999). Ketiga, keberadaan laporan keuangan tertulis (tradisional). Berkaitan dengan keberadaan laporan keuangan tradisional, para ahli berpandangan bahwa laporan keuangan tradisional akan masih tetap ada dan digunakan untuk memverifikasi akurasi dari informasi keuangan yang ada di internet. Pandangan ini menyatakan bahwa laporan keuangan tradisional digunakan untuk audit secara formal, kewajiban terhadap peraturan dan kemungkinan tidak tersedianya internet untuk semua orang (Xiao et.al.: 2002). Keempat, dampak terhadap pengguna informasi keuangan. Pengguna informasi 
keuangan di tempat yang jauh dan terpencil akan sangat terbantu dengan adanya penyajian informasi keuangan lewat internet. Demikian juga, analis dan investor akan mempunyai tambahan sumber informasi yang up-to-date (Xiao et.al.: 2002). Kelima, dampak terhadap peraturan dan standar akuntansi. Dikarenakan internet akan mempunyai jangkauan yang global dan menghilangkan batas-batas geografis, maka kebutuhan akan standard dan peraturan global akan diperlukan. Internet akan semakin mendorong kearah harmonisasi standar atau penggunaan standar Internasional. Dan ke-enam, dampak terhadap audit. Internet akan mendorong timbulnya real-time pelaporan keuangan, sehingga akan dibutuhkan system audit berkelanjutan yang dilakukan oleh auditor (Rezaee et.al: 2001, Richardson \& Scholz: 1999). Konsep audit kemungkinan besar tidak berubah, tetapi prektek audit akan berubah dengan perkembangan pelaporan lewat internet.

\section{Pengggunaan Internet Untuk 'Hubungan Investor' (Investor Relations)}

Menurut Deller et.el. (1999), hubungan investor (investor relations) dapat didefinisikan sebagai strategi perusahaan dalam berkomunikasi dengan investor yang ada dan investor potensial (Deller et.al.: 1999). Tujuan utama dari aktivitas hubungan investor adalah untuk menyediakan informasi yang dibutuhkan oleh investor dalam membuat keputusan alokasi modal. Lebih jauh lagi, aktivitas hubungan investor dapat dipandang sebagai alat untuk mengurangi atau menurunkan under atau overpice atas saham-saham perusahaan (Deller et.al.: 1999). Khususnya, yang terkait dengan penurunan persepsi atau underpricing.

Aktivitas hubungan investor juga sapat dipandang sebagai kemungkinan pengambilalihan yang tidak diinginkan dengan memberikan informasi yang memiliki relevansi nilai bagi partisipan pasar efisien, perusahaan dapat mempengaruhi nilai pasarnya dengan jalan memberikan informasi-informasi baru kepada partisipan pasar. Lebih jauh lagi, dari sudut pandang teori keagenan, aktivitas hubungan investor dapat menurunkan biaya keagenan (agency cost) dengan jalan menurunkan asimetri informasi.

Bentuk alat hubungan investor yang paling umum digunakan secara tradisional adalah laporan keuangan perusahaan, laporan interim, laporan tahunan, 
press release, hasil analisa, dan diskusi (Gunther \& Otterbein: 1996 dikutip dari Deller et.al.: 1999) yang dikirimkan atau diberikan melalui media pos.

Internet merupakan suatu alternetif media yang dapat digunakan untuk melakukan aktivitas hubungan investor dengan lebih efisien. Internet dalam hal ini menggabungkan antara kualitas informasi yang dapat diberikan kepada investor dengan biaya yang lebih ekonomis dalam memberikan informasi tersebut. Disamping itu, internet membawa bentuk baru alat hubungan investor yaitu diskusi interaktif melalui 'chat' dengan perwakilan dari perusahaan.

Menurut Deller et.al. (1999), penggunaan teknologi internet akan memungkinkan diaplikasikan untuk; 1) Distribusi laporan keuangan melalui internet, 2) Penyajian keunggulan perusahaan lewat diskusi manajemen, 3) Mengidentifikasi dan menelusuri pengguna hubungan investor melalui teknologi cookie, 4) Penyediaan press release dan layanan lain yang lebih up-to-date, 5) Memungkinkan komunikasi langsung melalui fasilitas.

\section{PEMBAHASAN}

Kerangka kerja Pirchegger \& Wagenhofer (Pirchegger \& Wagenhofer Framework) digunakan untuk menganalisa dari permasalahan yang ada, penjelasan secara rinci tentang hasil analisis data sebagai berikut.

\section{Ketersediaan dan Penggunaan Homepage}

Evaluasi dilakukan melalui fasilitas search engines (yahoo dan google) untuk mencari alamat homepage masing-masing perusahaan dengan memasukkan nama perusahaan atau kode listing ke dalam search engines. Penelitian ini menggunakan search engines (yahoo dan google) dikarenakan situs google atau yahoo sudah dipakai oleh masyarakat luas terutama pengguna internet dan mudah mendapatkan informasi yang dicari. Selain itu memiliki komoditas unggulan dalam jenis layanan pencarian informasi serta melakukan upaya lain dalam memperkaya layanan utamanya.

Dari hasil evaluasi ditemukan bahwa dari 45 perusahaan sampel, 2 perusahaan yang homepage-nya tidak dapat di akses, meskipun sebagian informasi keuangan dan profil perusahaan tercantum pada homepage Bursa Efek Indonesia. Ada 1 perusahaan yang tidak memliki homepage tersendiri melainkan perusahaan tersebut berada dalam website induknya yaitu Asia Pulp Paper (APP). Sedangkan 43 perusahaan sampel $(95,6 \%)$ memiliki homepage tersendiri yang dapat di akses. 
Dari 45 perusahaan yang memiliki homepage tersendiri, 2 perusahaan yang tidak dapat di akses homepage-nya yaitu Bakrieland Development Tbk dan Mitra Internetional Resources Tbk. Dapat dikatakan perusahaan-perusahaan tersebut merupakan perusahaan yang memiliki nama besar di Indonesia. Perusahaan yang tidak memiliki hompepage tersendiri tapi berada dalam homepage induknya yaitu Indah kiat Pulp \& Paper Tbk. Asia Pulp Paper (APP) memiliki fasilitas produksi di Indonesia. Upgrade terus-menerus dan perluasan produksi telah membuat APP tumbuh menjadi industri pulp dan kertas yang mempunyai anak perusahaan yang salah satunya PT. Indah Kiat Pulp \& Paper Tbk. Gambar 1 menunjukkan prosentase perbandingan perusahaan yang memliki homepage dan yang tidak memiliki homepage. Lebih jelas dapat dilihat pada grafik berikut:

Gambar 1

Ketersediaan dan Penggunaan Homepage

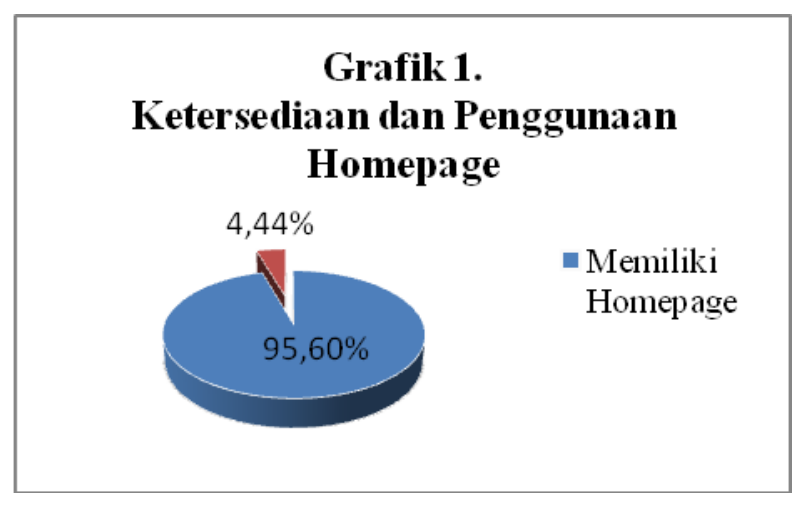

\section{Penggunaan Homepage Untuk Mengkomunikasikan Informasi Keuangan}

Analisa pertama dilakukan untuk menentukan keberadaan informasi-informasi keuangan dalam homepage masing-masing perusahaan. Tahap pertama ini dilakukan untuk menganalisa berapa banyak perusahaan yang memanfaatkan homepage mereka untuk menginformasikan informasi keuangan kepada pengguna. Pertama, keberadaan dan Kelengkapan Laporan Keuangan Pokok. Pada tahap ini, langkah awal dilakukan untuk menganalisa keberadaan informasi keuangan pokok, yaitu neraca, laba rugi, dan arus kas, serta kelengkapan neraca, laba rugi dan laporan arus kas yang di informasikan di homepage masing-masing perusahaan. Dari hasil analisa homepage 43 perusahaan, ditemukan bahwa sebanyak 37 perusahaan (86,05\%) menggunakan homepage mereka untuk menginformasikan neraca dan 6 perusahaan (13,95\%) tidak menginformasikan neraca. Dari 37 perusahaan yang menginformasikan neraca 
tersebut, 34 perusahaan $(91,89 \%)$ menyajikan neraca dalam format yang lengkap dan detail, sedangkan 3 perusahaan $(8,11 \%)$ yang lain hanya menyajikan sub total dari masing-masing sub bagian neraca saja, lihat Grafik 2.

Gambar 2

Keberadaan dan Kelengkapan Neraca

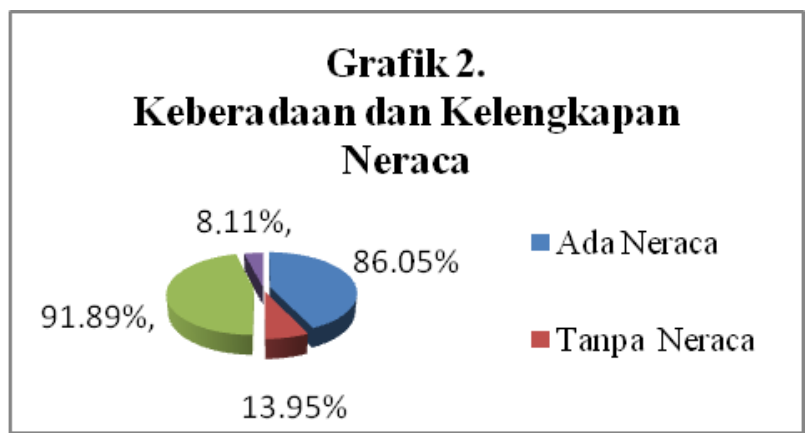

Berkaitan dengan laporan laba rugi, terdapat 38 perusahaan $(88,37 \%)$ yang menyajikan laporan laba rugi di homepage mereka, sedangkan sebanyak 5 perusahaan $(11,63 \%)$ tidak menggunakan homepage mereka untuk menginformasikan laporan laba rugi. Dari 38 perusahaan yang menyajikan laporan laba rugi, 35 perusahaan $(92,11 \%)$ menyajikan laporan laba rugi mereka di homepage dalam format yang lengkap, sedangkan 3 perusahaan $(7,89 \%)$ tidak menyajikan laporan laba rugi secara lengkap, hanya sebatas informasi penjualan, harga pokok dan laba bersih saja, seperti tampak pada gambar 3 berikut:

Gambar 3

Keberadaan dan Kelengkapan Laporan Laba Rugi

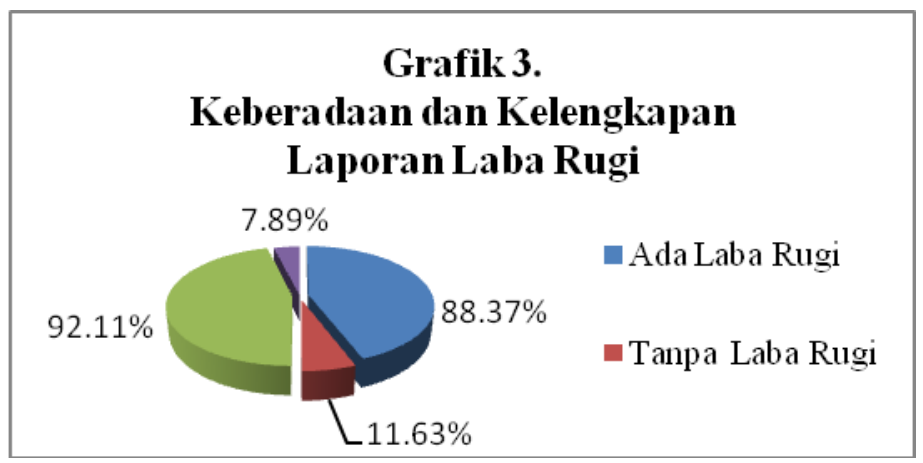

Laporan keuangan pokok yang ketiga adalah laporan arus kas. Berdasarkan hasil analisa, terdapat 30 perusahaan $(69,77 \%)$ yang menyajikan laporan arus kas 
dalam homepage mereka sedangkan 13 (30,23\%) yang lain tidak menyajikan laporan arus kas dalam homepage mereka. Untuk laporan arus kas, dari 30 perusahaan yang menyajikan laporan arus kas, menyajikannya dalam format dan bentuk yang lengkap, bukan hanya sub totalnya saja seperti tampak pada gambar 4

Gambar 4

Keberadaan Laporan Arus Kas

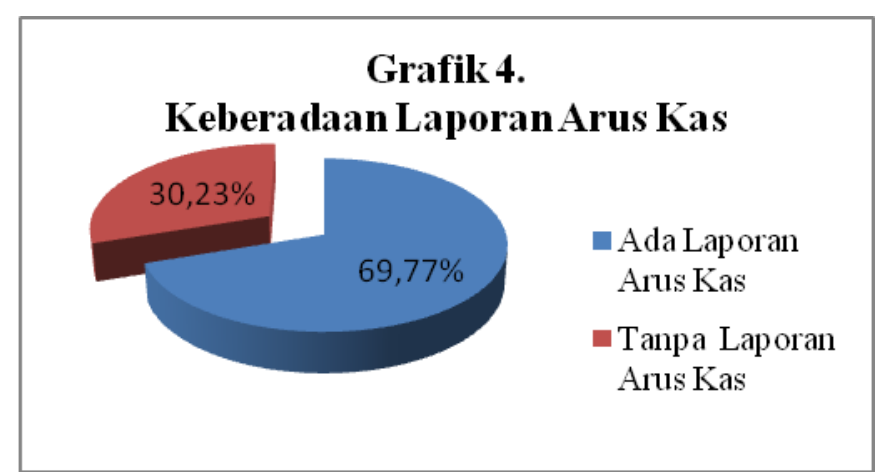

\section{Keberadaan Informasi Keuangan Tambahan}

Pada tahap ini, langkah awal dilakukan untuk menganalisa keberadaan informasi keuangan tambahan dinyatakan dengan keberadaan catatan atas laporan keuangan, analisa manajemen, dan opini auditor yang disajikan di homepage masing-masing perusahaan. Berdasarkan hasil analisa atas 43 perusahaan yang memiliki homepage, diperoleh hasil bahwa 33 perusahaan $(76,74 \%)$ menyajikan catatan atas laporan keuangan, sedangkan sisanya 10 perusahaan $(23,26 \%)$ tidak menyajikan. Hanya terdapat 6 perusahaan $(13,95 \%)$ yang menggunakan homepage-nya untuk menyajikan analisa manajemen (termasuk keberadaan rasio keuangan selama 3 tahun atau lebih), sedangkan 37 perusahaan $(86,05 \%)$ tidak memberikan fasilitas tersebut. Terdapat 11 perusahaan $(25,58 \%)$ memanfaatkan homepage untuk menginformasikan opini auditor atas audit laporan keuangan yang disajikan, sedangkan sisanya 32 perusahaan $(74,42 \%)$ tidak menyajikan opini auditor. Tidak semua perusahaan memanfaatkan homepage untuk menginformasikan opini auditor atas audit laporan keuangan yang disajikan pada gambar 5 
Gambar 5

Keberadaan Informasi Keuangan Tambahan

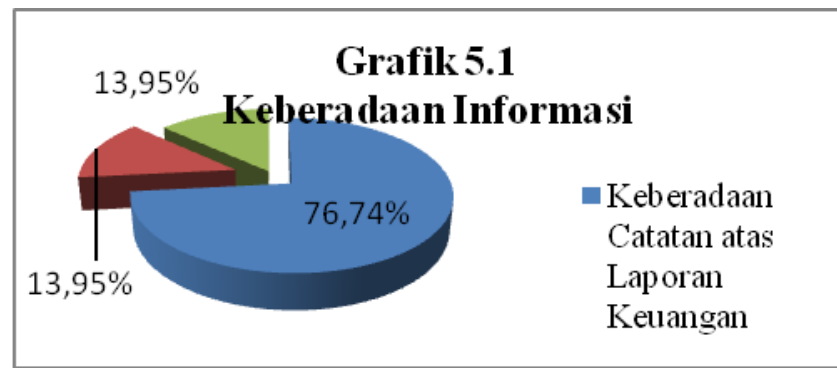

Gambar 6

Keberadaan Informasi Keuangan Tambahan

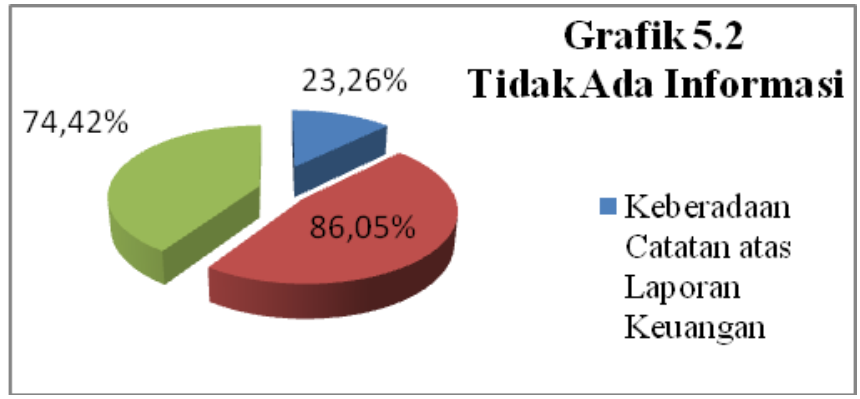

\section{Keberadaan Informasi Masa Lalu dan Laporan Interim}

Salah satu keunggulan internet adalah dihilangkannya pertukaran antara kedalaman informasi dan jangkauan informasi, diharapkan dengan penggunaan internet perusahaan dapat memberikan informasi yang lebih.

Pada tahap ini akan dianalisa sejauh mana dalam dimensi waktu historis keberadaan laporan keuangan tahunan yang diungkapkan di homepage perusahaan. Juga akan dianalisa, keberadaan laporan keuangan interim yang disajikan oleh perusahaan di homepagenya.

Dari hasil analisa 43 perusahaan sampel, ditemukan bahwa mayoritas perusahaan, 37 perusahaan $(86,05 \%)$ menyajikan laporan keuangan tahunan dalam dimensi waktu lebih dari 1 tahun. Disamping itu, 24 perusahaan (55,81\%) juga menyajikan laporan keuangan interim dalam homepage mereka, juga dalam dimensi waktu lebih dari satu kwartal seperti tampak pada grafik 6 
Gambar 6

Keberadaan Informasi Masa Lalu dan Laporan Interim

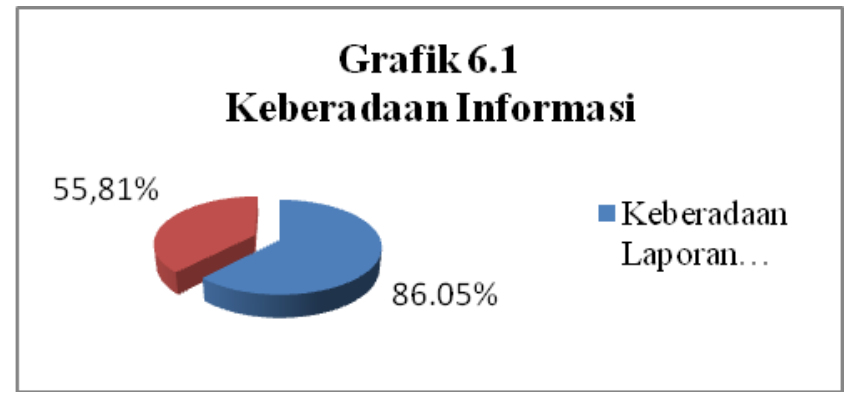

Gambar 6

Keberadaan Informasi Masa Lalu dan Laporan Interim

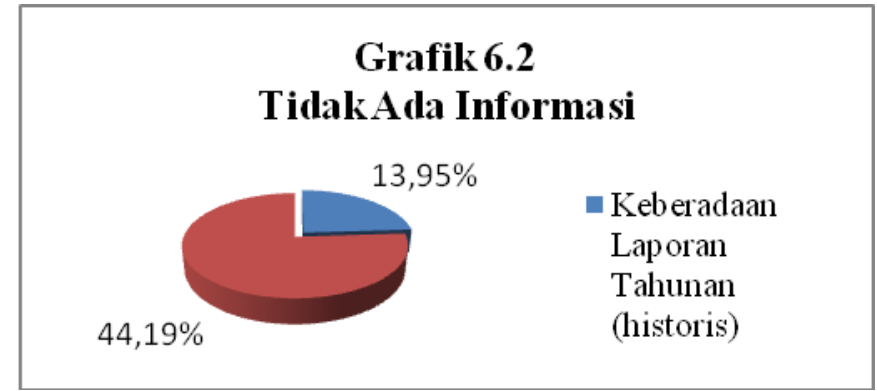

\section{Keberadaan Informasi Tambahan}

Keunggulan lain Internet adalah rendahnya biaya untuk menyampaikan informasi lebih secara mendalam (richness of information) kepada pengguna. Pada tahap ini akam dianalisa sejauhmana perusahaan-peruasahaan sampel memanfaatkan Internet untuk menyampaikan informasi tambahan sebagai nilai tambah perusahaan bagi pengguna informasi.

Dari hasil analisa 43 perusahaan sampel, ditemukan bahwa 39 perusahaan $(90,70 \%)$ memberikan tambahan informasi dalam bentuk press release. 27 perusahaan 
$(62,79 \%)$ memberikan dan menyajikan kuotasi harga saham per hari di homepage mereka, tetapi hanya 18 perusahaan (41,86\%) dari 43 perusahaan sampel yang menyajikan grafik pergerakan harga saham seperti tampak pada grafik 7

Gambar 4.7

Keberadaan Informasi Tambahan

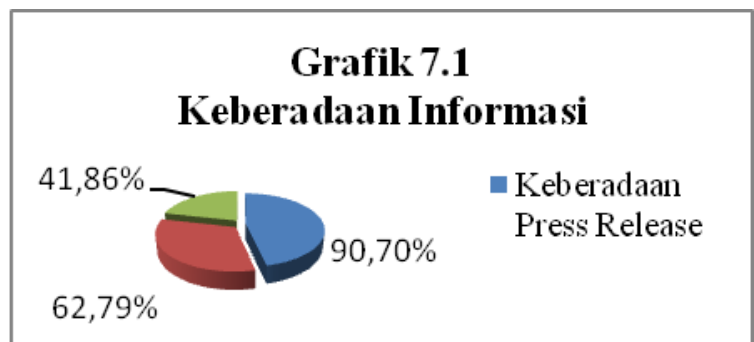

Gambar 4.7

Keberadaan Informasi Tambahan

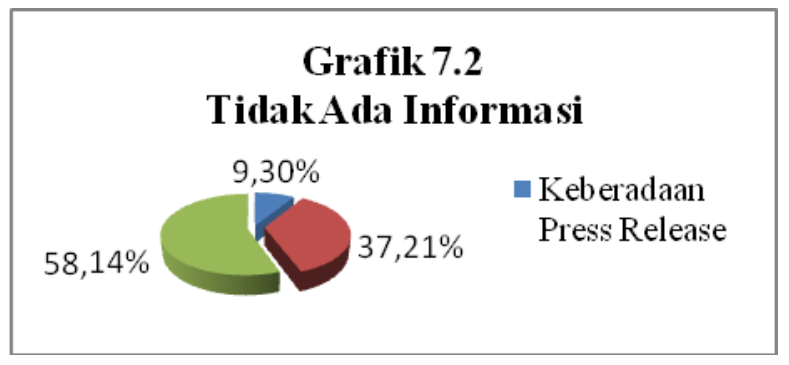

\section{Pemanfaatan Fitur-Fitur Internet Dalam Penyampaian Informasi}

Analisa yang kedua dilakukan untuk menentukan sejauhmana perusahaanperusahaan tersebut memanfatkan sepenuhnya keunggulan-keunggulan dari fiturfitur yang dimiliki oleh Internet. Pada tahap ini, akan dianalisa mengenai ketepatan waktu informasi yang disajikan, penggunaan teknologi dan user interface.

Pertama, Ketepatan Waktu Penyampaian Informasi. Pemanfaatan internet sebagai media penyampaian informasi memungkinkan diperolehnya biaya yang lebih rendah untuk menyajikan informasi secara dinamis. Dalam arti bahwa perusahaan mempunyai alternatif untuk selalu menyampaikan atau menyajikan informasiinformasi terbaru yang terjadi dan berpengaruh terhadap perusahaan kepada pengguna informasi, khususnya investor dengan biaya yang lebih rendah.

Pada tahap ini akan dianalisa seberapa jauh perusahaan melakukan update terhadap Website, menunjukkan perbedaan informasi terbaru dengan informasi yang lama, dan menunjukkan tanggal terakhir dilakukan update terhadap WebsiteDari 43 
perusahaan sampel yang memiliki homepage, terdapat 27 perusahaan $(62,79 \%)$ yang melakukan update terhadap homepage-nya, sedangkan 16 perusahaan $(37,21 \%)$ tidak melakukan update terhadap homepage. Dari 27 perusahaan yang melakukan update tersebut, 15 perusahaan (55,56\%) mencantumkan tanggal terakhir dilakukan update terhadap Website. Meskipun demikian hanya terdapat 4 perusahaan (9,30\%) dari 43 perusahaan sampel yang membedakan antara informasi yang terbaru dengan informasi yang lama, sedangkan 29 perusahaan $(67,44 \%)$ yang lain tidak mencantumkan perbedaan informasi baru dengan informasi yang lama seperti tampak pada grafik 8

Gambar 8

Ketepatan Waktu Penyampaian Informasi

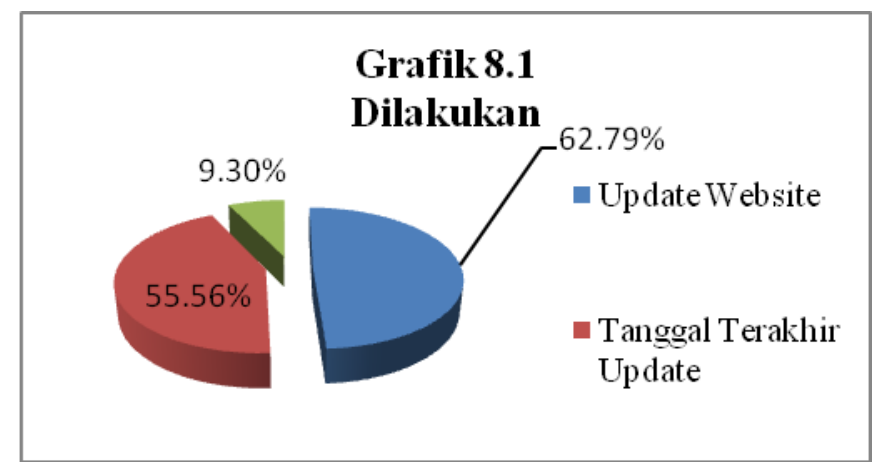

Gambar 8

Ketepatan Waktu Penyampaian Informasi

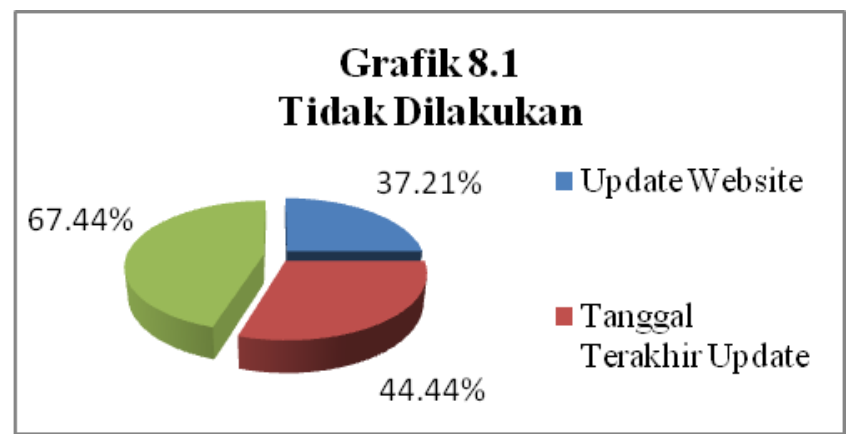

Kedua, penggunaan Teknologi Fitur-Fitur Internet. Internet sebagai alternatif media penyampaian informasi memberikan keunggulan-keunggulan teknis tertentu. Internet memiliki fitur-fitur yang tidak dimiliki oleh media informasi lain, misal : hyperlink teks, search engines, dan external links. Fitur-fitur tersebut merupakan keunggulan kompetitif internet dibandingkan dengan media-media yang lain. 
Pada tahap ini, akan dianalisa dari masing-masing homepage 43 perusahaan sampel, sejauhmana perusahaan tersebut memanfaatkan atau menggunakan teknologi fitur-fitur tersebut. Analisa akan dilakukan berkaitan dengan : kecepatan tampilan homepage, kecepatan tampilan halaman dengan informasi keuangan, keberadaan aplikasi JAVA (misalnya gambar bergerak), keberadaan Hyperlink text, keberadaan email, keberadaan petunjuk teknis, keberadaan fasilitas pencarian (search engines), keberadaan link eksternal dan ke-intuitif-an alamat homepage.

Berdasarkan 43 sampel perusahaan yang memiliki homepage, diketahui bahwa mayoritas homepage perusahaan, 36 perusahaan $(83,72 \%)$ dapat tampil dalam tempo relatif cepat. Demikian juga untuk halaman yang memuat informasi keuangan, 34 perusahaan $(79,07 \%)$ dapat menampilkan dalam waktu yang cepat. Sedangkan ratarata jumlah 'klik' yang dibutuhkan untuk menampilkan informasi keuangan sebanyak 2 sampai 3 klik.

Terdapat 38 perusahaan $(88,37 \%)$ yang memanfaatkan aplikasi JAVA terutama untuk menampilkan gambar bergerak (moving pictures). 30 perusahaan (69,77\%) menggunakan hyperlinks text dan 14 perusahaan (32,56\%) memiliki external links dalam homepage-nya. Sebanyak 37 perusahaan $(86,05 \%)$ mencantumkan alamat email yang dapat dihubungi, sedangkan 18 perusahaan (41,86\%) memberikan fasilitas direct email. Terdapat 33 perusahaan $(74,74 \%)$ yang memberikan fasilitas pencarian (search engines) dalam homepage mereka.

Mayoritas perusahaan sampel, sebanyak 28 perusahaan $(65,12 \%)$, memiliki alamat homepage yang intuitif, dalam arti bahwa alamat homepage tersebut mudah untuk dicari. Mayoritas perusahaan tersebut menggunakan nama perusahaan mereka atau singkatan huruf terdepan dari nama perusahaan mereka sebagai dasar alamat homepage-nya. Seperti tampak pada grafik 9

\section{Gambar 9}




\section{Penggunaan Teknologi Fitur-Fitur Internet}

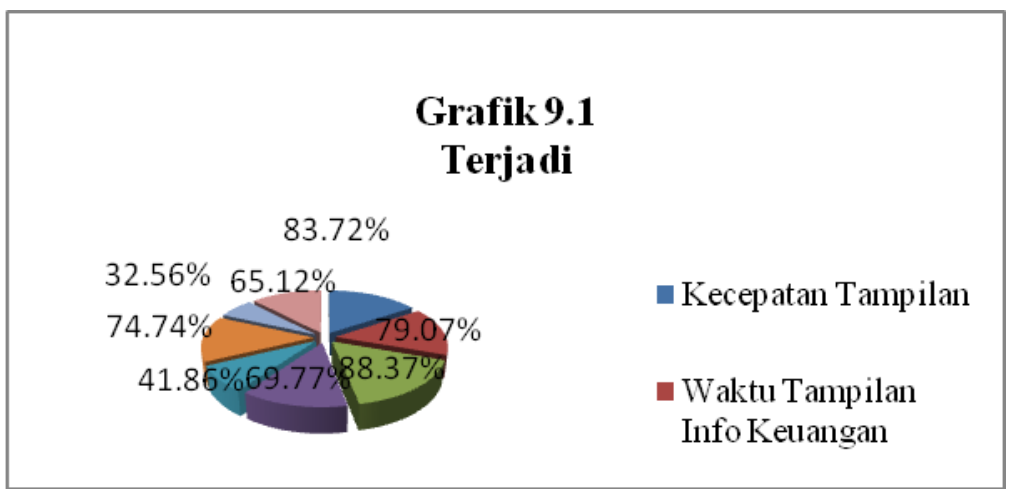

Gambar 9

Penggunaan Teknologi Fitur-Fitur Internet

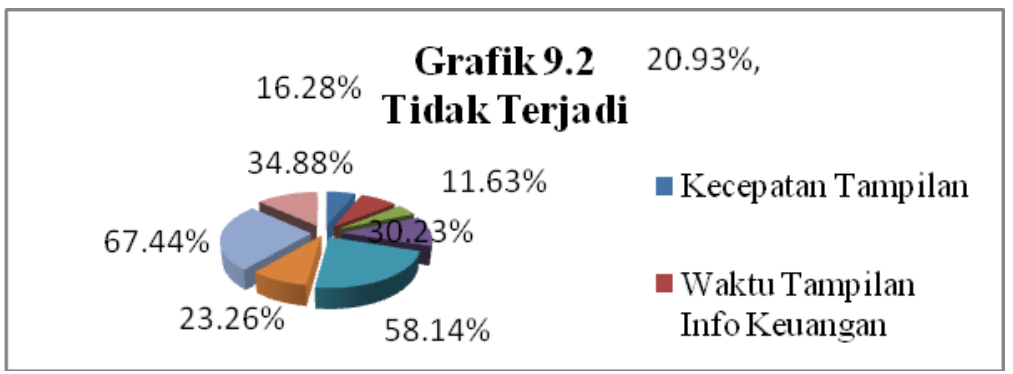

Ketiga, tampilan untuk pengguna homepage (Users Interface). Kandungan isi homepage, ketepatan waktu penyajian informasi maupun penggunaan secara optimal teknologi fitur-fitur internet belum dapat menjamin penggunaan homepage itu sendiri, faktor penting lain yang akan sangat mempengaruhi penggunaaan homepage adalah tampilan (interface) berupa layar monitor. Penggunaan frame, teks yang dapat jelas dibaca, struktur Web site, menu pull down dan site map akan sangat berpengaruh ke kemudahan penggunaan homepage.

Analisa dilakukan atas 43 perusahaan yang memiliki homepage, untuk menentukan: seberapa mudah tampilan mereka untuk pengguna yang dilihat dari elemen penggunaan frame, teks yang dapat jelas dibaca, struktur Web site, penjelasan informasi teknis, fasilitas download, menu pull down dan site map.

Dari 43 perusahaan yang memiliki homepage yang dapat diakses, semua homepage perusahaan $(100 \%)$ memiliki teks yang dapat dibaca dengan jelas dan mayoritas perusahaan, 32 perusahaan $(74,42 \%)$ menggunakan frame dalam me-layout Web site 
mereka. Meskipun hanya 74,42\% perusahaan yang mendesain dengan menggunakan frame, 40 perusahaan $(93,94 \%)$ mempunyai Web site yang terstruktur dengan baik sehingga memudahkan pengguna mencari informasi.

Dari perusahaan sampel, hanya 12 perusahaan (27,91\%) yang mencantumkan penjelasan informasi-informasi teknis, seperti format dokumen dan besarnya dokumen. 30 perusahaan $(69,77 \%)$ menyajikan fasilitas download dalam bentuk file .pdf, sedangkan beberapa perusahaan menyajikan informasinya dalam bentuk HTML (Hypertext Mark-up Language). 28 perusahaan (65,12\%) menyajikan menu site map dan 14 perusahaan (32,56\%) terdapat menu pull down seperti tampak pada grafik 10

Gambar 10

Tampilan Untuk Pengguna Homepage (Users Interface)

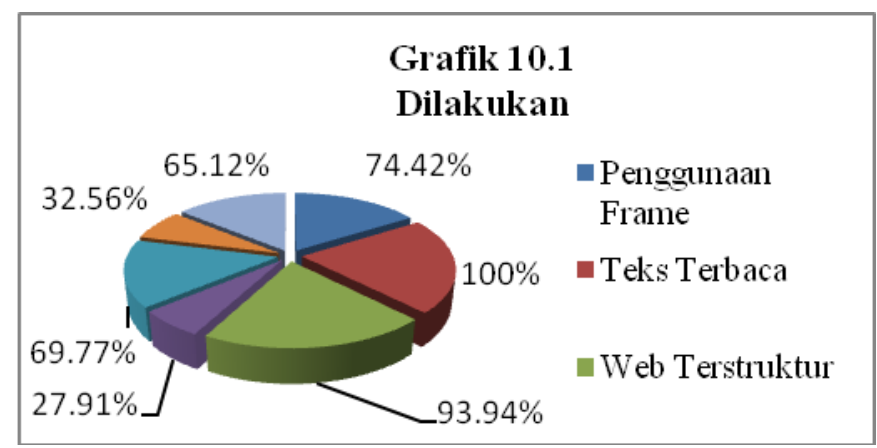

Gambar 10

Tampilan Untuk Pengguna Homepage (Users Interface)

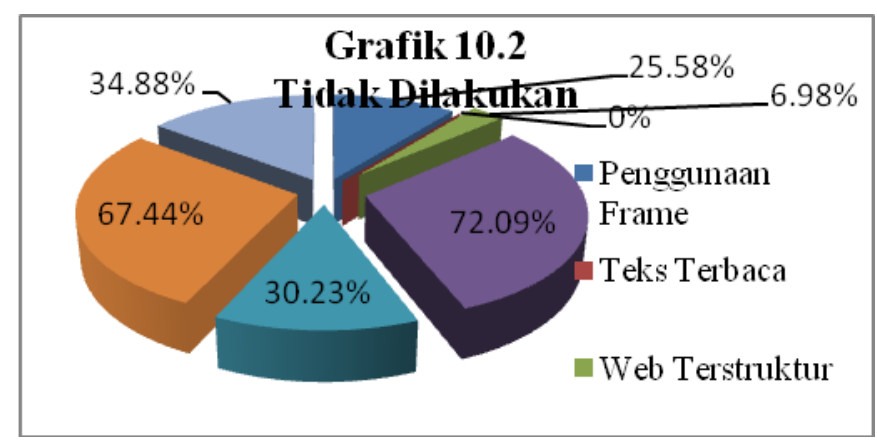

Berkaitan dengan versi bahasa yang digunakan di homepage. Mengingat bahwa perusahaan-perusahaan sampel merupakan perusahan yang berlokasi di 
Indonesia, terdapat 13 perusahaan $(30,23 \%)$ hanya menggunakan bahasa Inggris sebagai bahasa pengantar di Web site, sedangkan 30 perusahaan $(69,77 \%)$ menggunakan dua versi bahasa, Inggris dan Indonesia.

\section{KESIMPULAN}

Mayoritas perusahaan sampel $(95,6 \%)$ dalam penelitian ini memiliki Web site tersendiri, perusahaan sampel yang memiliki website tidak mencantumkan kode efek perusahaan dalam website mereka dan mayoritas $(86,05 \%)$ memanfaatkan homepage mereka untuk menginformasikan informasi keuangan terutama laporan keuangan pokok yaitu neraca dan laba rugi. Tidak banyak, kurang dari $80 \%$ perusahaan yang memberikan informasi keuangan tambahan (catatan atas laporan keuangan, pendapat auditor dan analisis manajemen). Mayoritas perusahaan sampel dalam penelitian ini hanya memberikan duplikasi informasi atau sebagian dari informasi hard copy laporan historis yang diubah dalam bentuk hypertext atau format pdf. Tidak banyak perusahaan sampel dalam penelitian ini yang benar-benar memanfaatkan fitur-fitur Internet secara optimal. Hal ini terbukti, kurang dari $42 \%$ dari perusahaan sampel yang menyampaikan informasi mengenai pergerakan saham. Disamping itu, meskipun mayoritas home page menampilkan press release, tetapi kurang dari $40 \%$ yang melakukan update atas informasi yang ditampilkan. Mayoritas perusahaan sampel dalam penelitian ini telah menggunakan teknologi yang cukup maju. Hal ini dibuktikan dengan kecepatan menampilkan informasi $(84 \%)$, penggunaan aplikasi JAVA untuk mempercantik tampilan, penggunaan hyperlinks dan external links dalam homepagenya. Disamping itu, mayoritas tampilan (interface) dari perusahaan sampel sudah terstruktur dengan baik.

\section{DAFTAR PUSTAKA}


AICPA, 1994. Improving Business Reporting - A Customer Focus. New York: Report of the AICPA Special Committee on Financial Reporting

Almilia Spica, 2009. Eksporasi Pemanfaatan Technology dan User Support Pada Website Perusahaan Go Publik di Indonesia. Seminar Nasional Aplikasi Teknologi Informasi 2009 (SNATI 2009). Yogyakarta

Almilia, Spica, 2009. Analisa Komparasi Indeks Internet Financial Reporting Pada Website Perusahaan Go Publik di Indonesia. Seminar Nasional Aplikasi Teknologi Informasi 2009 (SNATI 2009). Yogyakarta

Choi, Meck. 2002. International Accounting. $4^{\text {th }}$ Ed., Pearson Education Ltd.

Darma Henwa Tbk (http://www.ptdh.co.id/, diakses 23 Mei 2010)

Deller, Stubenrath, Weber. 1999. A Survey on The Use of The Internet for Investor Relations in The USA, The UK and Germany. The European Accounting Review, Vol. 8, Iss. 2, pp. $351-364$

Elnusa Tbk (http://www.elnusa.co.id/, diakses 23 Mei 2010)

Energi Mega Persada (http://www.energi-mp.com/, diakses 23 Mei 2010)

Hapsari, Mirma dan Imam Ghozali. 2003. Pengaruh Teknologi Informasi berbasis Sumber Daya terhadap Kinerja Perusahaan. Jurnal Akuntansi Maksi Vol. 6 No. 1 pp $60-68$

IAI. 2009. Pernyataan Standar Akuntansi Keuangan (revisi 2009), (Online) (http://www.google.com, diakses 20 Mei 2010)

Indonesia Stock Exchange (http:// www.idx.co.id/, diakses 19 Mei 2010)

Indriantoro, Nur. 2002. Metode Penelitian Bisnis. Edisi Pertama. Yogyakarta: BPFE.

Lestari, Sri dan Chariri. 2009. Analisis Faktor-Faktor Yang Mempengaruhi Pelaporan Keuangan Melalui Internet (Internet Financial Reporting) Dalam Website Perusahaan. Semarang: Universitas Diponegoro.

Lymer, A. 1999. The Internet and the Future of Corporate Reporting in Europe. The European Accounting Review, Vol. 8, Iss. 2, pp. 289 - 301

Oetomo, Wibowo, Hartono, Prakoso. 2007. Pengantar Teknologi Informasi Internet, Konsep dan Aplikasi. Yogyakarta: Penerbit Andi.

Pirchegger, Wagenhofer. 1999. Financial Information on The Internet: A Survey of The Homepages of Austrian Companies. The European Accounting Review, Vol. 8, Iss. 2, pp. $383-395$ 
Xiao, Jones, Lymer. 2002. Immediate Trends in Internet Reporting. The European Accounting Review, Vol. 11, Iss. 2, pp. 245 - 275 